\title{
First biochemical characterization of a novel ribonuclease from wild mushroom Amanita hemibapha
}

\author{
Malota Sekete ${ }^{1}$, Duanzheng Ma', Bo Wang ${ }^{2}$, Hexiang Wang ${ }^{1 *}$ and Tzibun $\mathrm{Ng}^{3^{*}}$
}

\begin{abstract}
A 45-kDa ribonuclease (RNase) was purified from dried fruiting bodies of the wild mushroom Amanita hemibapha. It was adsorbed on DEAE-cellulose, S-sepharose, and finally purified on Superdex 75. The RNase exhibited maximal RNase activity at $\mathrm{pH} 5$ and in a temperature range between $60-70^{\circ} \mathrm{C}$. It demonstrated no ribonucleolytic activity toward four polyhomoribonucleotides. The amino acid sequence analysis (GDDETFWEHEWAK) showed this RNase was a ribonuclease T2-like RNase. It exhibited strong inhibitory activity against HIV-1 reverse transcriptase (HIV-1 RT) with an $\mathrm{IC}_{50}$ of $17 \mu \mathrm{M}$.
\end{abstract}

Keywords: Ribonuclease, Mushroom, Purification

\section{Introduction}

Ribonucleases (RNases) exist in a wide range of life forms from prokaryotes to eukaryotes (Fang and $\mathrm{Ng}$. 2010). RNases from different mushrooms also differ in biochemical properties such as molecular weight, carbohydrate content, and $\mathrm{N}$-terminal sequence among others (Wang and Ng. 2006). RNases isolated from different tissues may have different structures (Hofsteenge et al. 1989; Iwama et al. 1993; Sasso et al. 1991) and it has long been claimed that wild mushrooms are beneficial to health in manifestation of anti-tumor (Kobayashi et al. 2000), antiviral and antifungal (Wang and Ng. 2000), immunomodulatory (Matousek et al. 1995; Fang and Ng. 2010) and immunosuppressive activities (Wang and Ng. 2000; Ngai et al. 2003). In this manner, their potential clinical importance may also one day find application in the treatment of chronic diseases such as cancer and HIV- 1 infection.

Ribonucleases are capable of offering protective measures to various organisms due to their host defense mechanisms (Wong et al. 2010). Ribonucleases isolated from roots of Panax ginseng (Chinese ginseng), P. notoginseng (sanchi ginseng), and P. quinquefolius (American ginseng) have

\footnotetext{
* Correspondence: hxwang@cau.edu.cn; b021770@mailserv.cuhk.edu.hk

${ }^{1}$ State Key Laboratory for Agrobiotechnology and Department of Microbiology, China Agricultural University, Beijing 100193, China Full list of author information is available at the end of the article
}

antifungal properties (Wang and Ng. 2000). RNases of both Chinese and American ginseng are homodimeric and demonstrate HIV-1 reverse transcriptase inhibitory activity (Wang and Ng, 2000).

RNases play a key role in RNA metabolism. They are involved in host defense and physiological cell death pathways. RNases possess therapeutic potentials for cancer treatment, as RNA damage caused by RNases could be an important alternative to standard DNA-damaging chemotherapeutics. (Makarov and Ilinskaya. 2003). Four members of the RNase A superfamily : Onconase from oocytes of Rana pipiens, BS-RNase from bull semen, and two closely related sialic acid-binding lectins from oocytes of Rana catesbeiana and Rana japonica are endowed with antitumor activity and show cytotoxicity toward several tumor cell lines (Notomista et al. 2000).

In the present study, a ribonuclease was isolated from the fryiting bodies of Amanita hemibapha for determination of biochemical characteristics and comparison with previously reported ribonucleases.

\section{Materials and Methods}

Dried fruiting bodies of the mushroom Amanita hemibapha from Sichuan China were homogenized in $0.15 \mathrm{M} \mathrm{NaCl}$ solution using a Waring blender, and then stored at $4^{\circ} \mathrm{C}$ overnight before centrifugation (10000 g, $15 \mathrm{~min})$. Ammonium sulfate precipitation 


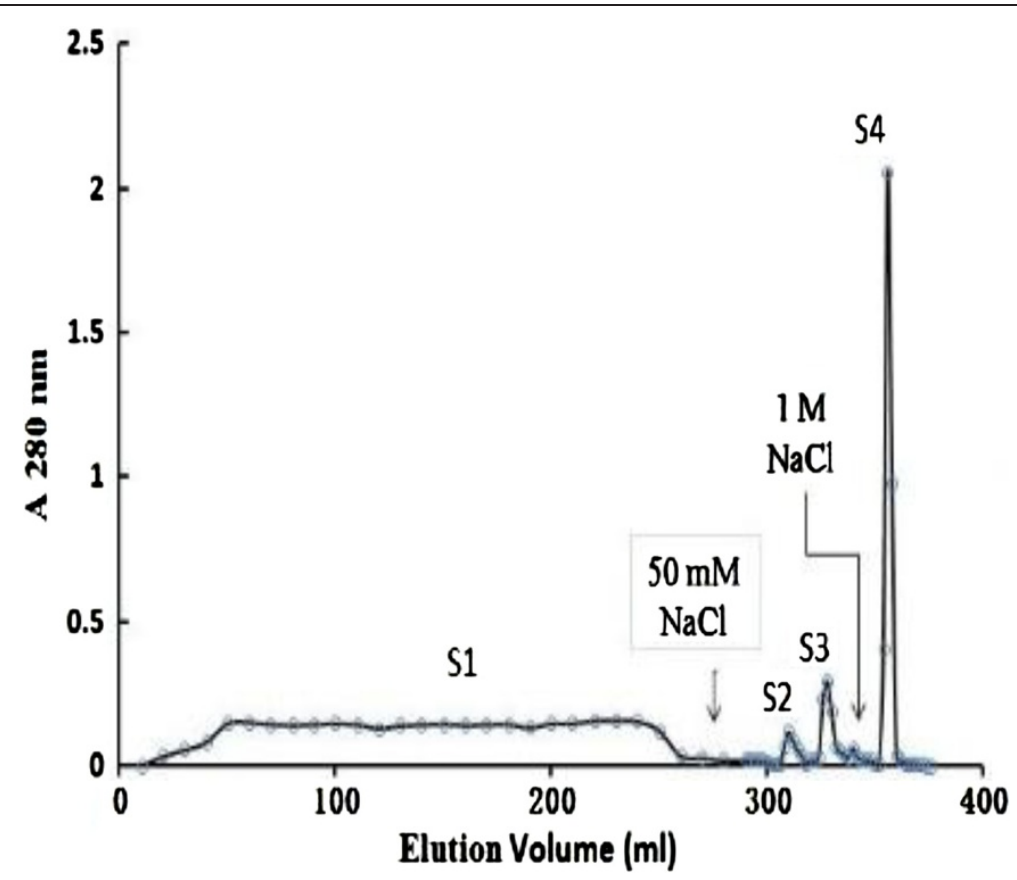

Figure 1 Cation exchange chromatography of D3 on a S-Sepharose column which was first eluted with $10 \mathrm{mmol} / \mathrm{L} \mathrm{HAc-NaAc} \mathrm{buffer}$ $(\mathrm{pH}$ 3.6) and then stepwise with $50 \mathrm{mM}$ and $1 \mathrm{M} \mathrm{NaCl}$ in the buffer. RNase was detected only in fraction S3.

was carried out by adding $\left(\mathrm{NH}_{4}\right)_{2} \mathrm{SO}_{4}$ to the supernatant to $80 \%$ saturation to precipitate proteins. After centrifugation (10000 g, $15 \mathrm{~min}$ ), the precipitated proteins were dissolved in distilled water and dialyzed to remove $\left(\mathrm{NH}_{4}\right)_{2} \mathrm{SO}_{4}$. NaAc-HAc buffer (pH 5.6, $1 \mathrm{M}$ ) was added to the solution, until the concentration of $\mathrm{NaAc}$ reached $10 \mathrm{mM}$. The supernatant was subjected to ion exchange chromatography on a column of DEAE-cellulose (Sigma) in $10 \mathrm{mM}$ NaAc-HAc buffer (pH 5.6). After elution of unadsorbed proteins (fraction D1) with the same buffer, adsorbed proteins were desorbed sequentially with $50 \mathrm{mM}$ $\mathrm{NaCl}, 150 \mathrm{mM} \mathrm{NaCl}$, and $1 \mathrm{M} \mathrm{NaCl}$ to yield fractions $\mathrm{D} 2$, D3, and D4, respectively. Fraction D3 with RNase activity was dialyzed and subsequently chromatographed on a

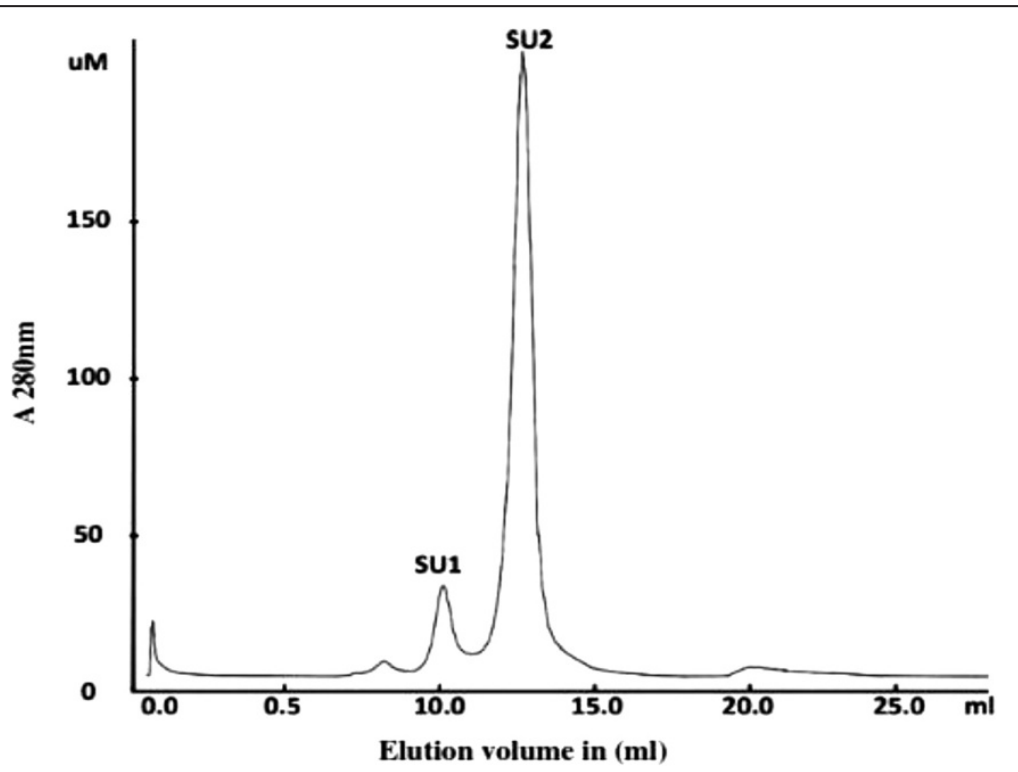

Figure 2 FPLC-gel filtration of fraction S3 on a Superdex 75 HR10/30 column. Buffer: $0.15 \mathrm{M} \mathrm{NH}_{4} \mathrm{HCO}_{3}(\mathrm{pH} 8.5)$. Flow rate: $0.4 \mathrm{ml} / \mathrm{min}$. Fraction size: $0.8 \mathrm{ml}$. RNase activity was confined to fraction SU1. 
Table 1 Yields and RNase activities of various chromatographic fractions

\begin{tabular}{llllll}
\hline Column & Fractions & $\begin{array}{l}\text { Yield } \\
(\mathbf{m g})\end{array}$ & $\begin{array}{l}\text { Specific } \\
\text { activity } \\
\text { (U/mg) }\end{array}$ & $\begin{array}{l}\text { Recovery of } \\
\text { RNase } \\
\text { activity (\%) }\end{array}$ & $\begin{array}{l}\text { Purification } \\
\text { fold }\end{array}$ \\
\hline & $\begin{array}{l}\text { Ammonium } \\
\text { sulfate } \\
\text { precipitate }\end{array}$ & $\mathbf{5 4 0}$ & $\mathbf{1 4 . 2 4}$ & $\mathbf{1 0 0}$ & $\mathbf{1}$ \\
\hline $\begin{array}{l}\text { DEAE- } \\
\text { cellulose }\end{array}$ & D1 & 12.85 & 15.38 & $<3$ & - \\
\cline { 2 - 6 } & D2 & 23.7 & 8.15 & $<3$ & - \\
\cline { 2 - 6 } & D3 & $\mathbf{8 2 . 3 6}$ & $\mathbf{5 3 . 2 1}$ & $\mathbf{5 6 . 9 9}$ & $\mathbf{3 . 7 4}$ \\
\cline { 2 - 6 } & D4 & 255.7 & 2.79 & $<10$ & - \\
\hline S-sepharose & D3S1 & 37.5 & - & - & - \\
\cline { 2 - 6 } & D3S2 & 0.24 & - & - & - \\
\cline { 2 - 6 } & D3S3 & $\mathbf{6 . 7 8}$ & $\mathbf{1 8 6 . 0 7}$ & $\mathbf{1 6 . 4 1}$ & $\mathbf{1 3 . 0 7}$ \\
\cline { 2 - 6 } & D3S4 & 34 & - & - & - \\
\hline Superdex 75 & D3S3SU1 & $\mathbf{0 . 0 6}$ & $\mathbf{6 7 4 6 . 6 7}$ & $\mathbf{5 . 2 9}$ & $\mathbf{4 7 3 . 7 8}$ \\
\cline { 2 - 6 } & D3S3SU2 & 0.697 & - & - & - \\
\hline
\end{tabular}

$2.5 \times 10 \mathrm{~cm}$ of $\mathrm{S}$-Sepharose (Sigma) in $10 \mathrm{mM} \mathrm{NaAc-}$ HAc buffer ( $\mathrm{pH}$ 3.6). After removal of unadsorbed proteins (fraction S1), adsorbed proteins were eluted with a linear concentration gradient $(0-500 \mathrm{mM})$ of $\mathrm{NaCl}$ and $1 \mathrm{M} \mathrm{NaCl}$ in $10 \mathrm{mM} \mathrm{NaAc-HAc}$ buffer (pH 3.6) to yield fraction S2 and S3. The peak (S3) with RNase activity was then further purified on a Superdex 75 HR 10/30 column (GE health) in $0.15 \mathrm{M} \mathrm{NH}_{4} \mathrm{HCO}_{3}$ buffer (pH 8.5). The first peak (SU1) obtained represented purified RNase.

\section{Assay for activity of ribonuclease}

Activity of A. hemibapha RNase toward yeast tRNA (Sigma) was assayed by measuring the production of acidsoluble, UV-absorbing species with a modification of the method of (Wang and Ng 2003a). The RNase was incubated with $100 \mu \mathrm{g}$ of tRNA in $150 \mu \mathrm{l} 100 \mathrm{mM}$ MES buffer $(\mathrm{pH} 4.6)$ at $37^{\circ} \mathrm{C}$ for $15 \mathrm{~min}$. The reaction was terminated by addition of $350 \mu \mathrm{l}$ of $3.7 \%$ perchloric acid. The sample was centrifuged at $15,000 \mathrm{~g}$ for $5 \mathrm{~min}$. The absorbance of the resulting supernatant, after suitable dilution, was measured at $260 \mathrm{~nm}$. One unit of enzymatic activity is defined as the amount of enzyme that produces an absorbance increase at $260 \mathrm{~nm}$ of one per minute in the acid-soluble fraction per milliliter of reaction mixture under the specified conditions. The optimal $\mathrm{pH}$ and temperature were determined following the same method as described using buffer with different $\mathrm{pH}$ values as the reaction buffer and different temperatures instead of $37^{\circ} \mathrm{C}$.

Molecular mass determination by sodium dodecyl sulfate polyacrylamide gel electrophoresis (SDS-PAGE) and by FPLC-gel filtration

SDS-PAGE was conducted in accordance with the procedure of (Laemmli and Favre 1973) using a 12\% resolving

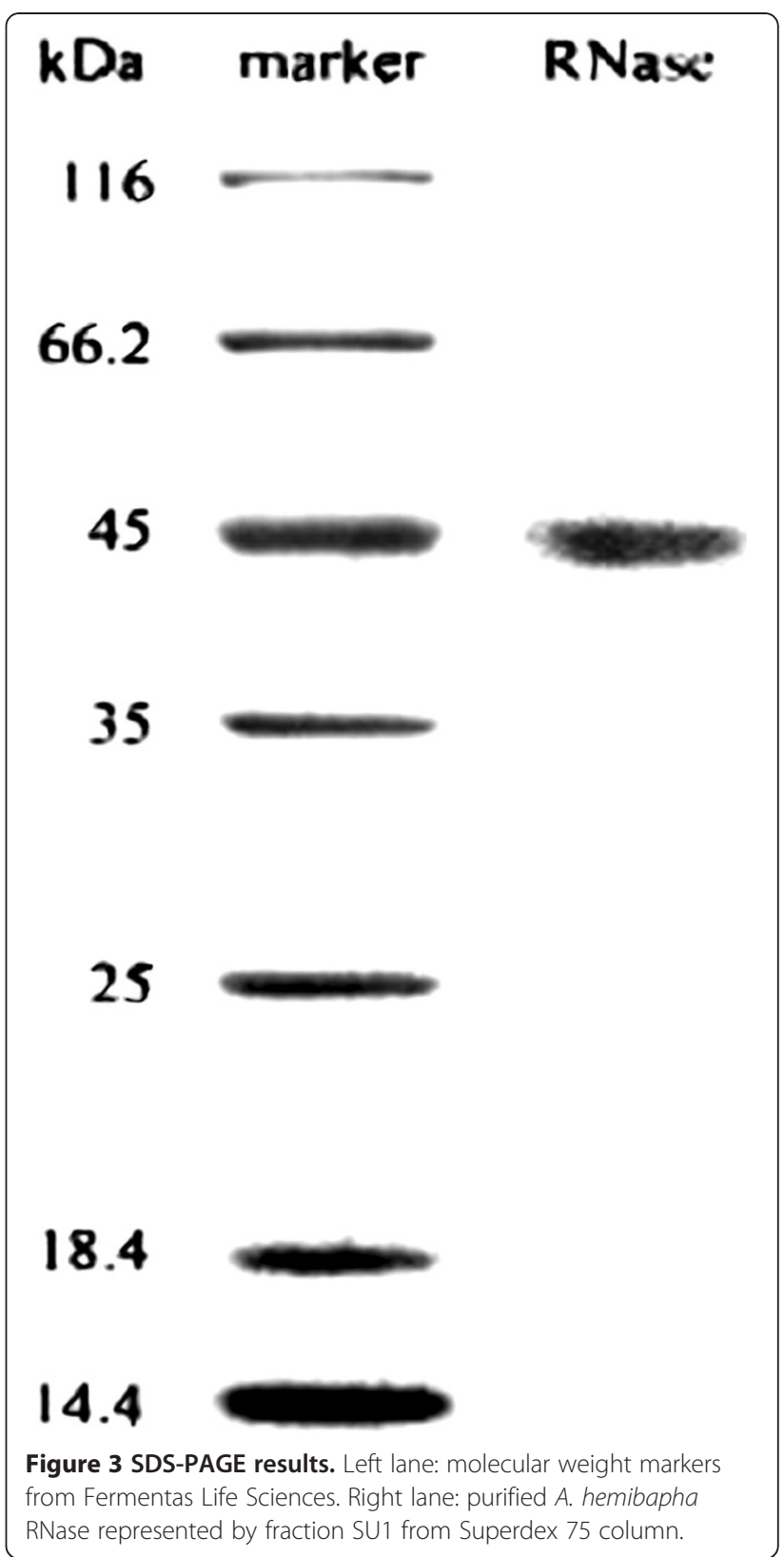

gel and a 5\% stacking gel. At the end of electrophoresis, the gel was stained with Coomassie brilliant blue. FPLCgel filtration was carried out using a Superdex 75 HR $10 / 30$ column that had previously been calibrated with molecular-mass standards using an AKTA Purifier (GE Healthcare).

\section{Analysis of partial amino acid sequence}

The single band of the purified RNase from SDS-PAGE was cut out and sent to National Center of Biomedical Analysis (Beijing) for analysis of amino acid sequence by Q-TOF. 
Table 2 Partial sequence of $A$. hemibapha RNase in comparison with other reported RNases

\begin{tabular}{lll}
\hline Protein & Sequence & Accession \\
\hline A. hemibapha RNase of this study & GDDETFWEHEWAK & EFZ03379.1 \\
\hline ribonuclease Trv [Metarhizium anisopliae] & 125 GDDETFWEHEWAK 137 & XP_003335329.1 \\
\hline ribonuclease T2 [Puccinia graminis] & 144 GNDETFWEHEWAK 156 & XP_003023932.1 \\
\hline ribonuclease T2 family, putative [Trichophyton verrucosum] & 125 GDDETFWEHEWNK 137 & BAK32788.1 \\
\hline ribonuclease T2 [Morchella esculenta] & 124 GDDESFWEHEWSK 136 & EGX96697.1 \\
\hline ribonuclease M [Cordyceps militaris] & 117 GDDESFWEHEWGK 129 & XP_001214320.1 \\
\hline ribonuclease T2 precursor [Aspergillus terreus] & 123 GDDESFWEHEWNK 135 & XP_753027.1 \\
\hline ribonuclease T2 [Aspergillus fumigates] & 128 GDDESFWEHEWNK 140 & XP_002947011.1 \\
\hline S-like RNase [Volvox carteri] & 120 DETFWEHEWSK 130 &
\end{tabular}

Different amino acid residues are underlined. Data are taken from NCBI BLAST.

\section{Activity of $A$. hemibapha RNase toward polyhomoribonucleotides}

The ribonucleolytic activity of $A$. hemibapha RNase toward polyhomoribonucleotides was determined with a modification of the method of (Wang and Ng 2001). Incubation of $A$. hemibapha RNase with $100 \mu \mathrm{g}$ of poly A, poly C, poly G or poly $\mathrm{U}$ in $250 \mu \mathrm{l}$ of $100 \mathrm{mM}$ sodium acetate $(\mathrm{pH} 5.0)$ was carried out at $37^{\circ} \mathrm{C}$ for $1 \mathrm{~h}$, prior to addition of $250 \mu \mathrm{l}$ of ice-cold $1.2 \mathrm{~N}$ perchloric acid containing $20 \mathrm{mM}$ lanthanum nitrate to terminate the reaction. After $15 \mathrm{~min}$ on ice, the sample was centrifuged at $15,000 \times \mathrm{g}$ for $15 \mathrm{~min}$ at $4^{\circ} \mathrm{C}$. The absorbance of the supernatant, after appropriate dilution, was read at $260 \mathrm{~nm}$ (for poly A, poly G and poly U) or at $280 \mathrm{~nm}$ (for poly C).
Assay for ability to inhibit human immunodeficiency virus reverse transcriptase (HIV-1 RT)

The assay for ability of $A$. hemibapha RNase to inhibit HIV-1 RT activity was carried out as detailed by (Collins et al. 1997) using a non-radioactive reverse transcriptase ELISA kit. The assay was executed following instructions supplied with the assay kit from Boehringer- Mannheim (Germany). The assay uses the ability to synthesize DNA with reverse transcriptase, starting from the template/ primer hybrid poly(A) oligo $(\mathrm{dT})_{15}$. The digoxigenin- and biotin-labeled nucleotides in an optimized ratio are incorporated into one of the same DNA molecule, which is freshly synthesized by the reverse transcriptase (RT). The detection and quantification of synthesized DNA as a parameter for RT activity follow an ELISA protocol.

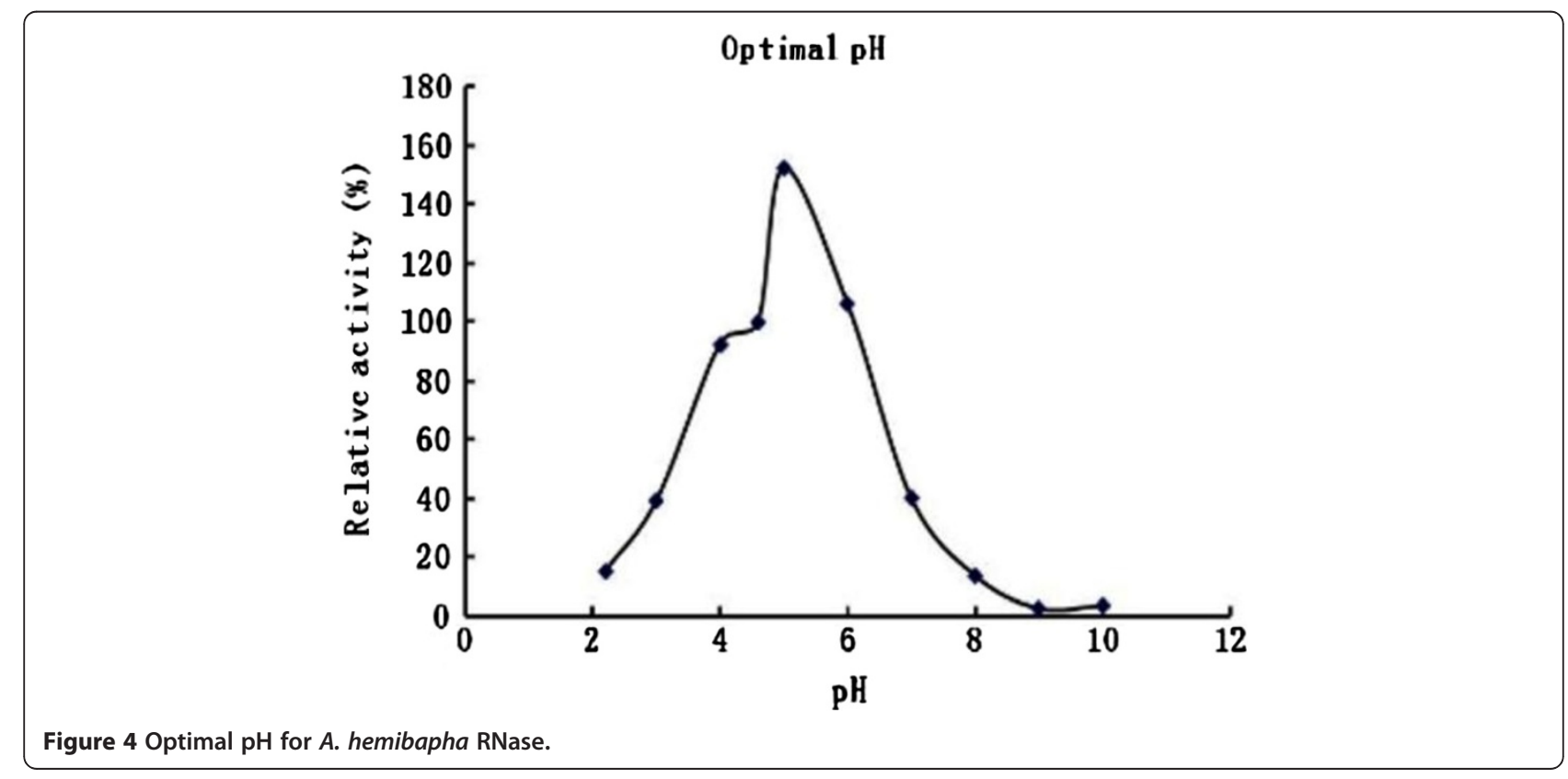




\section{Optimal Temperature}

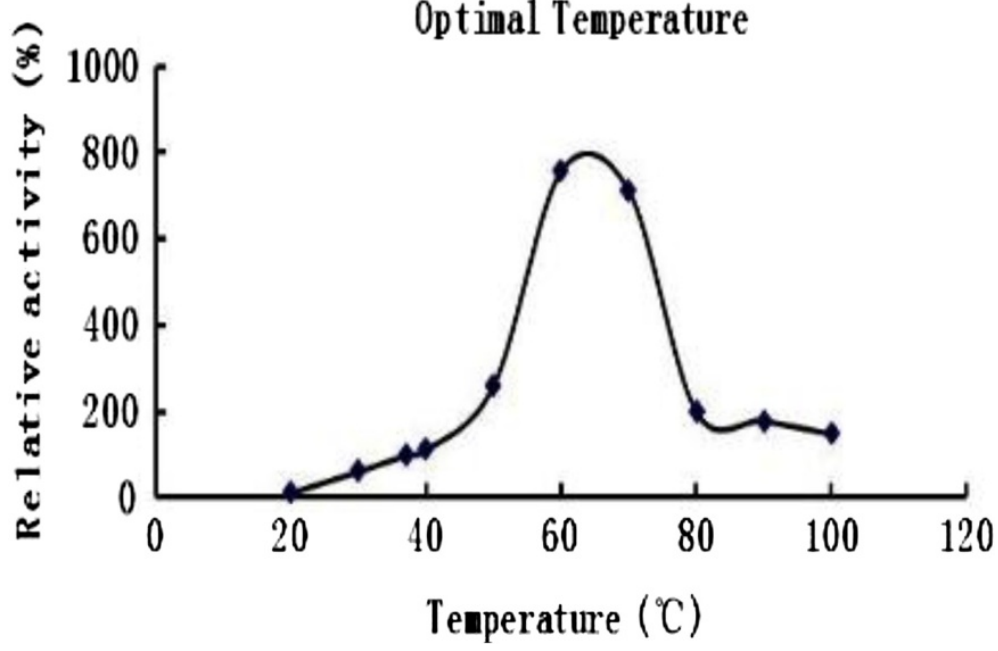

Figure 5 Optimal temperature for A. hemibapha RNase.

Biotin labeled DNA binds to the surface of microtiter plate modules that have been pre pre-coated with streptavidin. In the next step, an antibody to digoxigenin, conjugated to peroxidase, binds to the digoxigenin-labeled DNA. In the final step, the peroxidase substrate is added. The peroxidase enzymes catalyze the cleavage of the substrate, producing a colored reaction product. The absorbance of the samples at $405 \mathrm{~nm}$ can be determined using microtiter plate (ELISA) reader and is directly correlated to the level of RT activity. A fixed amount (4-6 ng) of recombinant HIV-1 reverse transcriptase was used. The inhibitory activity of the isolated ribonuclease was calculated as percent inhibition as compared to a control without the protein (Collins et al. 1997).

\section{Results}

Ion exchange chromatography of the crude sample on a DEAE-cellulose column yielded four fractions: D1 eluted

Table 3 Comparison of characteristics of various mushroom ribonucleases

\begin{tabular}{|c|c|c|c|c|c|c|c|}
\hline & \multirow{2}{*}{$\begin{array}{l}\text { Mol } \\
\text { mass } \\
(\mathrm{kDa})\end{array}$} & \multirow{2}{*}{$\begin{array}{l}\text { Optimum } \\
\text { pH }\end{array}$} & \multirow{2}{*}{$\begin{array}{l}\text { Optimum } \\
\text { temperature }\end{array}$} & \multirow{2}{*}{$\begin{array}{l}\text { HIV-1 RT } \\
\text { inhibitory activity } \\
\left(\mathrm{IC}_{50} \text { in } \mu \mathrm{M}\right)\end{array}$} & \multicolumn{3}{|c|}{ Antiproliferative activity $\left(\mathrm{IC}_{50}\right.$ in $\left.\mu \mathrm{M}\right)$} \\
\hline & & & & & L1210 cells & Hep G2 cells & MCF-7 cells \\
\hline A. hemibapha & 45 & 5.0 & $60 \sim 70$ & 17 & ND & UD & UD \\
\hline Boletus griseus & 29 & 3.5 & $60-70$ & ND & ND & ND & ND \\
\hline Clitocybe maxima & 17.5 & $6.5,7.0$ & 70 & ND & ND & ND & ND \\
\hline Dictyophora indusiata & 28 & $4-4.5$ & 60 & ND & ND & ND & ND \\
\hline Ganoderma lucidum & 42 & 4 & 60 & ND & ND & ND & ND \\
\hline Hypsizigus marmoreus & 18 & 5 & 70 & ND & 60 & ND & ND \\
\hline Lyophyllum shimeiji & 14.5 & 6 & 70 & 7.2 & ND & 10 & 6.2 \\
\hline Pleurotus djamor & 15 & 4.6 & 60 & ND & ND & 3.9 & 3.4 \\
\hline Pleurotus eryngii & 16 & 6.5 & 70 & ND & ND & ND & ND \\
\hline Pleurotus ostreatus (Nomura et al.) & 12.4 & 8.0 & ND & ND & ND & ND & ND \\
\hline Pleurotus ostreatus (Ye et al.) & 12 & 7.0 & 40 & ND & ND & ND & $\mathrm{ND}$ \\
\hline Pleurotus pulmonarius & 14.4 & 7 & 55 & ND & ND & ND & ND \\
\hline Pleurotus sajor-caju & 12 & 5.5 & $<60$ & ND & 0.1 & 0.22 & ND \\
\hline Pleurotus tuber-regium & 29 & 6.5 & ND & ND & ND & ND & $\mathrm{ND}$ \\
\hline Russula delica & 14 & 5 & 60 & UD & ND & 8.6 & 7.2 \\
\hline Russulus virescens & 28 & 4.5 & 60 & ND & ND & ND & ND \\
\hline Thelephora ganbajun & 30 & $6-7$ & 40 & 0.3 & ND & ND & ND \\
\hline Volvariella volvacea & 42.5 & $6.5,-7.5$ & ND & ND & ND & ND & ND \\
\hline
\end{tabular}


with the starting buffer, and D2, D3, and D4 eluted sequentially with $50 \mathrm{mM} \mathrm{NaCl}, 150 \mathrm{mM} \mathrm{NaCl}$, and $1 \mathrm{M} \mathrm{NaCl}$ in the buffer. Ribonuclease activity was detected only in fraction D3. D3 was separated on a S-Sepharose column into a broad unadsorbed fraction S1 eluted with the starting buffer, and two smaller fractions S2 and S3 eluted with 50 $\mathrm{mM} \mathrm{NaCl}$ in the buffer, and the fraction S4 eluted with 1 $\mathrm{M} \mathrm{NaCl}$ in the buffer (Figure 1). S3 was separated on Superdex 75 into a smaller peak (SU1) with activity and a large peak (SU2) without ribonuclease activity (Figure 2). The smaller fraction SU1 represented purified ribonuclease and exhibited a single band with a molecular mass of 45 $\mathrm{kDa}$ in SDS-PAGE (Table 1, Figure 3).

The sequence of one peptide from T-TOF analysis was GDDETFWEHEWAK, which showed high homology (up to 100\%) with Ribonuclease Trv and Ribonuclease T2 of many microorganisms by BLAST search. These ribonuclease sequences are compared in Table 2.

The activity of ribonuclease reached a maximum at $\mathrm{pH}$ 5.0, and dropped precipitously when the $\mathrm{pH}$ was lowered below 4 or raised above 7 (Figure 4). The optimal temperature was $60 \sim 70^{\circ} \mathrm{C}$ (Figure 5). A. hemibapha RNase inhibited HIV-1 reverse transcriptase with an $\mathrm{IC}_{50}$ of $17 \mu \mathrm{M}$. A comparison of A. hemibapha RNase with previously published mushroom RNases is shown as a supplement in Table 3.

\section{Discussion}

A 45-kDa ribonuclease (RNase) purified from dried fruiting bodies of the wild mushroom Amanita hemibapha is reported herein. Its molecular size of $45 \mathrm{kDa}$ falls outside the range exhibited by all mushroom ribonucleases (9-45 $\mathrm{kDa}$ ) reported so far, being greater than that of straw mushroom (42 kDa) (Wang and Ng. 1999). RNases from Boletus griseus (Wang and Ng. 2006), Clitocybe maxima (Wang and Ng. 2004a), Dictyophora indusiata (Wang and Ng. 2003a), Hypsizigus marmoreus (Guan et al. 2007), Lyophyllum shimeiji (Zhang et al. 2010), Pleurotus djamor (Wu et al. 2010), Pleurotus eryngii (Ng and Wang, 2004), Pleurotus ostreatus (Ye and Ng. 2003), Pleurotus pulmonarius (Ye and Ng, 2002), Pleurotus sajor-caju (Ngai and Ng. 2004), Pleurotus tuber-regium (Wang and Ng. 2001), Russula delica (Zhao et al. 2010), Russulus virescens (Wang and Ng 2003b) and Thelephora ganbajun (Wang and $\mathrm{Ng} 2004 \mathrm{~b}$ ), are all smaller than $32 \mathrm{kDa}$ while those of Ganoderma lucidum (Wang et al. 2004) and Volvariella volvacea (Wang and Ng. 1999) are higher than $30 \mathrm{kDa}$ but less than $45 \mathrm{kDa}$. A. hemibapha RNase demonstrated no ribonucleolytic activity toward four polyhomoribonucleotides. Most reported RNases such as $P$. tuber-regium (Wang and Ng. 2001) and P. ostreatus (Nomura et al. 1994) RNases are specific for poly G. L. edodes RNase exhibits preference for polyA (Kobayashi et al. 1992). Others like an ubiquitin-like peptide from mushroom
Cantharellus cibarius (Wang et al. 2003) showed ribonuclease activity against various polyhomoribonucleotides.

The optimum $\mathrm{pH}$ was 5 and the optimal temperature was $60 \sim 70^{\circ} \mathrm{C}$. Its optimum $\mathrm{pH}$ is very different from that of Russulus virescens ribonuclease (optimum $\mathrm{pH}$ of 4.5) (Wang and Ng 2003b) and of Ganoderma lucidum ribonuclease (optimum $\mathrm{pH}$ of 4.0) (Wang et al. 2004). The temperature dependence curve for the activity of $A$. hemibapha ribonuclease indicates that it is a fairly thermostable enzyme. It retains more than half of its maximal activity at $80^{\circ} \mathrm{C}$ and is totally inactivated only at $100^{\circ} \mathrm{C}$. The partial sequence of $A$. hemibapha RNase reveals $100 \%$ similarity to ribonuclease Trv [Metarhizium anisopliae] and slight difference from ribonuclease T2 [Puccinia graminis], ribonuclease T2 family, putative [Trichophyton verrucosum], ribonuclease T2 [Morchella esculenta], ribonuclease $\mathrm{M}$ [Cordyceps militaris], ribonuclease T2 precursor [Aspergillus terreus], ribonuclease T2 [Aspergillus fumigatus], S-like RNase [Volvox carteri] as depicted in Table 2. But this RNase inhibited HIV-1 reverse transcriptase with an $\mathrm{IC}_{50}$ of $17 \mu \mathrm{M}$. This antiHIV-1 reverse transcriptase activity has not been demonstrated for the majority of the previously isolated mushroom RNases.

\section{Competing interests}

The authors declare that they have no competing interests.

\section{Authors' contributions}

SM purified and characterized the ribonuclease. MD performed the assay of inhibitory activity against HIV-1 reverse transcriptase and WB collected the wild mushroom Amanita hemibapha used in the investigation. WH was the principal investigator, research grant holder and supervised the research team. NTB assisted in the writing and proofreading of the article. All authors read and approved the final manuscript.

\section{Acknowledgments}

This work was financially supported by National Grants of China (2010CB732202).

\section{Author details}

${ }^{1}$ State Key Laboratory for Agrobiotechnology and Department of Microbiology, China Agricultural University, Beijing 100193, China. ${ }^{2}$ Soil and Fertilizer Institute, Sichuan Academy of Agricultural Sciences, Sichuan 610066, China. ${ }^{3}$ School of Biomedical Sciences, Faculty of Medicine, The Chinese University of Hong Kong, Shatin, New Territories, Shatin, Hong Kong, China.

Received: 22 September 2012 Accepted: 4 December 2012 Published: 27 December 2012

\section{References}

Collins RA, Ng TB, Fong WP, Wan CC, Yeung HW (1997) A comparison of human immunodeficiency virus type 1 inhibition by partially purified aqueous extracts of Chinese medicinal herbs. Life Sci 60:L345-L351

Fang EF, Ng TB (2010) Ribonucleases of different origins with a wide spectrum of medicinal applications. Biochimica et Biophysica Acta 1815:65-74

Guan GP, Wang HX, Ng TB (2007) A novel ribonuclease with antiproliferative activity from fresh fruiting bodies of the edible mushroom Hypsizigus marmoreus. Biochim Biophys Acta 1770:1593-1597

Hofsteenge J, Matthies R, Stone SR (1989) Primary structure of a ribonuclease from porcine liver, a new member of the ribonuclease superfamily. Biochemistry 28:9806-9813 
Iwama M, Sanda A, Ohgi K, Hofsteenge J, Irie M (1993) Purification and primary structure of a porcine kidney non-secretory ribonuclease. Biosci Biotechnol Biochem 57:2133-2138

Kobayashi H, Inokuchi N, Koyama T, Watanabe H, Iwami M, Ohgi K (1992) Primary structure of a base nonspecific and adenylic acid preferential ribonuclease from the fruit bodies of Lentinula edodes. Biosci Biotechnol Biochem 55:2003-2010

Kobayashi H, Hara J, Itagaki T, Inokuchi N, Koyama T, Sanda A, Iwama M, Ohgi K, Irie M (2000) Relationship of two ribonucleases with molecular masses of $45 \mathrm{kDa}$ and $37 \mathrm{kDa}$ from the culture medium of Lentinula edodes. Biol Pharm Bull 23:800-804

Laemmli U, Favre M (1973) Gel electrophoresis of proteins. J Mol Biol 80:575-599

Makarov AA, llinskaya ON (2003) Cytotoxic ribonucleases: molecular weapons and their targets. FEBS Lett 540(1-3):15-20

Matousek J, Soucek J, Riha J, Zankel TR, Benner SA (1995) Immunosuppressive activity of angiogenin in comparison with bovine seminal ribonuclease and pancreatic ribonuclease. Comp Biochem Physiol B Biochem Mol Biol 112:235-241

$\mathrm{Ng}$ TB, Wang HX (2004) A novel ribonuclease from fruiting bodies of the common edible mushroom Pleurotus eryngii. Peptides 25:1365-1368

Ngai PHK, Ng TB (2004) A ribonuclease with antimicrobial, antimitogenic and antiproliferative activities from the edible mushroom Pleurotus sajor-caju. Peptides 25:11-17

Ngai PH, Wang HX, Ng TB (2003) Purification and characterization of a ubiquitinlike peptide with macrophage stimulating, antiproliferative and ribonuclease activities from the mushroom Agrocybe cylindracea. Peptides 24:639-645

Nomura H, Inokuchi N, Kobayashi H, Koyama T, Iwama M, Ohgi K (1994) Purification and primary structure of a new guanylic acid specific ribonuclease from Pleurotus ostreatus. J Biochem 116:26-33

Notomista E, Catanzano F, Graziano G, Dal Piaz F, Barone G, D'Alessio G, Di Donato A (2000) Onconase: An unusually stable protein. Biochemistry 39:8711-8718

Sasso MP, Carsana A, Confalone E, Cosi C, Sorrentino S, Viola M, Palmieri M, Russo E, Furia A (1991) Molecular cloning of the gene encoding the bovine brain ribonuclease and its expression in different regions of the brain. Nucleic Acids Res 19:6469-6474

Wang H, Ng TB (1999) Isolation of a new ribonuclease from fresh fruiting bodies of the straw mushroom. Biochem Biophys Res Commun 264:714-718

Wang HX, Ng TB (2000) Quinqueginsin, a novel protein with anti-human immunodeficiency virus, antifungal, ribonuclease and cell-free translationinhibitory activities from American ginseng roots. Biochem Biophys Res Commun 269:203-208

Wang HX, Ng TB (2001) Purification and characterization of a potent homodimeric guanine-specific ribonuclease from fresh mushroom (Pleurotus tuber-regium) sclerotia. Int J Biochem Cell Biol 33:483-490

Wang H, Ng TB (2003a) A novel ribonuclease from the veiled lady mushroom Dictyophora indusiata. Biochem Cell Biol 81:373-377

Wang H, Ng TB (2003b) A ribonuclease with distinctive features from the wild green-headed mushroom Russulus virescens. Biochem Biophys Res Commun 312:965-968

Wang H, Ng TB (2004a) Isolation of a new ribonuclease from fruiting bodies of the silver plate mushroom Clitocybe maxima. Peptides 25:935-939

Wang HX, Ng TB (2004b) Purification of a novel ribonuclease from dried fruiting bodies of the edible wild mushroom Thelephora ganbajun. Biochem Biophys Res Commun 324:855-859

Wang H, Ng TB (2006) A ribonuclease from the wild mushroom Boletus griseus. Appl Microbiol Biotechnol 72:912-916

Wang HX, Ngai HK, Ng TB (2003) A ubiquitin-like peptide with ribonuclease activity against various polyhomoribonucleotides from the mushroom Cantharellus cibarius. Peptides 24:509-513

Wang HX, Ng TB, Chiu SW (2004) A distinctive ribonuclease from fresh fruiting bodies of the medicinal mushroom Ganoderma lucidum. Biochem Biophys Res Commun 314:519-522

Wong JH, Ng TB, Randy CF, Cheung Ye XJ, Wang HX, Lam SK, Lin P, Chan YS, Evandro FF, Patrick Ngai HK, Xia LX, Ye XY, Jiang Y, Liu F (2010) Proteins with antifungal properties and other medicinal applications from plants and mushrooms. Appl Microbiol Biotechnol 87:1221-1235, a minireview

Wu X, Zheng S, Cui L, Wang H, Ng TB (2010) Isolation and characterization of a novel ribonuclease from the pink oyster mushroom Pleurotus djamor. The Journal of general and applied microbiology 56(3):231-239
Ye XY, Ng TB (2002) A novel and potent ribonuclease from fruiting bodies of the mushroom Pleurotus pulmonarius. Biochem Biophys Res Commun 293:857-861

Ye XY, Ng TB (2003) Purification and characterization of a new ribonuclease from fruiting bodies of the oyster mushroom Pleurotus ostreatus. J Pept Sci 9:120-124

Zhang RY, Zhang GQ, Hu DD, Wang HX, Ng TB (2010) A novel ribonuclease with antiproliferative activity from fresh fruiting bodies of the edible mushroom Lyophyllum shimeiji. Biochem Genet 48:658-668

Zhao S, Zhao Y, Li S, Zhang G, Wang H, Ng TB (2010) An antiproliferative ribonuclease from fruiting bodies of the wild mushroom Russula delica. J Microbiol Biotechnol 20:693-699

\section{doi:10.1186/2193-1801-1-79}

Cite this article as: Sekete et al:: First biochemical characterization of a novel ribonuclease from wild mushroom Amanita hemibapha.

SpringerPlus 2012 1:79.

\section{Submit your manuscript to a SpringerOpen ${ }^{\odot}$ journal and benefit from:}

- Convenient online submission

- Rigorous peer review

- Immediate publication on acceptance

- Open access: articles freely available online

- High visibility within the field

- Retaining the copyright to your article

Submit your next manuscript at $>$ springeropen.com 